\title{
Type 2 iodothyronine deiodinase is highly expressed in germ cells of adult rat testis
}

\author{
Simone Magagnin Wajner*, Márcia dos Santos Wagner*, Rossana C N Melo , Gleydes G Parreira², \\ Hélio Chiarini-Garcia ${ }^{2}$, Antonio C Bianco ${ }^{3}$, Csaba Fekete ${ }^{4,5}$, Edith Sanchez ${ }^{5}$, Ronald M Lechan ${ }^{5}$ \\ and Ana Luiza Maia
}

Endocrine Division, Thyroid Section, Hospital de Clínicas de Porto Alegre, Universidade Federal do Rio Grande do Sul, Porto Alegre, Rio Grande do Sul, Brazil ${ }^{1}$ Laboratory of Cellular Biology, Department of Biology, Universidade Federal de Juiz de Fora, Juiz de Fora, Minas Gerais, Brazil

${ }^{2}$ Laboratory of Structural Biology and Reproduction, Department of Morphology, Universidade Federal de Minas Gerais, Belo Horizonte, Brazil

${ }^{3}$ Division of Endocrinology, Diabetes and Hypertension, Brigham and Women's Hospital and Harvard Medical School, Boston, Massachusetts, USA

${ }^{4}$ Department of Endocrine Neurobiology, Institute of Experimental Medicine, Hungarian Academy of Sciences, Budapest H-1083, Hungary

${ }^{5}$ Division of Endocrinology, Diabetes, and Metabolism, Tufts-New England Medical Center, Boston, Massachusetts, USA

(Requests for offprints should be addressed to A L Maia who is now at Setor de Tireóide, Serviço de Endocrinologia, Hospital de Clínicas de Porto Alegre, Rua Ramiro Barcelos, 2350, 90035-003 Porto Alegre, Rio Grande do Sul, Brazil; Email: almaia@ufrgs.br)

*(S M Wajner and M dos Santos Wagner contributed equally to this study)

\begin{abstract}
The testis has been classically described as a thyroid hormone unresponsive tissue, but recent studies indicate that these hormones might play an important role in developing testes. We have previously demonstrated that type 2 iodothyronine deiodinase (D2), a thyroid hormone-activating enzyme, is expressed in adult rodent testis and that its activity is induced by hypothyroidism. Nevertheless, the precise location of D2 in testis is not known. The aim of the present work was to determine the testicular cell types in which D2 is expressed using real-time PCR analysis, in situ hybridization histochemistry, and determination of D2 activity in cell fractions isolated from adult euthyroid and/or hypothyroid rat testis. The D2 mRNA levels in germ cells were higher than those from somatic cells $(6.94 \pm 1.49$ vs $2.32 \pm 0.79$ arbitrary units (au); $P=0 \cdot 017)$. Hypothyroidism increased D2 expression in germ cells $(6.94 \pm 1.49$ vs $8.78 \pm 5.43$ au, $P=0.002)$ but did
\end{abstract}

not change D2 transcripts in somatic cells significantly $(2 \cdot 12 \pm 0.79$ vs $2.88 \pm 1.39$ au, $P=0.50)$. In situ hybridization analysis showed that D2 mRNA is specifically present in elongated spermatids undergoing differentiation, whereas other germ cell types and Sertoli cells of seminiferous epithelium and the interstitial cells were virtually negative for this enzyme. The enzyme activity measured in germ and somatic isolated cell fractions $(0.23 \pm 0.003$ vs $0.02 \pm$ $0.013 \mathrm{fmol} / \mathrm{min}$ per $\mathrm{mg}$ protein respectively; $P<0 \cdot 001)$ further confirmed the real-time PCR and in situ hybridization results. Hence, our findings demonstrated that D2 is predominantly expressed in elongated spermatids, suggesting that thyroid hormone might have a direct effect on spermatogenesis in the adult rats.

Journal of Endocrinology (2007) 194, 47-54

\section{Introduction}

The iodothyronine deiodinases types 1, 2, and 3 (D1, D2, and D3) constitute a family of oxidoreductases that catalyze the removal of iodine from the outer ring (D1 and D2, activation) or inner ring (D3, inactivation) of the thyroid hormones (Bianco et al. 2002). All the three deiodinases contain the uncommon amino acid selenocysteine in their active site, an essential residue for efficient catalysis (Berry et al. 1992, Croteau et al. 1995, Salvatore et al. 1995). Thyroxine $\left(T_{4}\right)$ activation to tri-iodothyronine $\left(T_{3}\right)$ via $\mathrm{D} 2$ allows for changes in intracellular thyroid status in a tissue-specific manner independent of serum $T_{3}$. This system has been extensively characterized in the brain, pituitary, and brown adipose tissue
(BAT). Recent studies suggest that D2 also contributes to a significant fraction of plasma $\mathrm{T}_{3}$ in rodents and humans (Maia et al. 2005, Streckfuss et al. 2005, Schneider et al. 2006). Although several factors such as cold, fasting, and hormones influence deiodinases activities, their main regulator is thyroid status. Hypothyroidism results in an increase of D2 activity and opposite changes are noted in hyperthyroidism (Bianco et al. 2002).

The testis was considered for years to be a thyroid hormone unresponsive organ, a concept based on data showing minimal levels of testicular thyroid hormone receptors (TRs) and lack of thyroid hormone effects on oxygen consumption in adult rat testes (Oppenheimer et al. 1974). However, clinical reports and experimental studies performed 
during the last decades have indicated that thyroid hormones might have critical effects of this organ, especially during development (Jannini et al. 1995, Sakai et al. 2004). Abnormalities on reproductive hormone production, ejaculated volume, sperm motility, and structural morphology of rat and human testes have been associated with altered thyroid hormone status (Buzzard et al. 2000, Carani et al. 2005).

Indeed, experimental evidence supports the concept that thyroid hormones are important for testicular development and function. The ontogenic pattern of expression of the various TR subtypes in human and rat testes has been studied. TR $\propto 1$ isoform was shown to be present in testis throughout development, from fetal life to adulthood, being maximally expressed in the perinatal period in both species (Buzzard et al. 2000, Jannini et al. 2000, Canale et al. 2001). Recently, a detailed testis morphological analysis was performed on $r d w$ mutant rats that have congenital hypothyroidism due to a missense mutation in the thyroglobulin gene (Sakai et al. 2004). The $r d w$ testis requires a longer time to develop and shortly after full maturation, the normal structure begins to degenerate, indicating that thyroid hormone plays a role in developing and maintaining normal testicular function. Moreover, determination of the expression profile of the deiodinases demonstrated that $\mathrm{D} 2$, a $\mathrm{T}_{4}$-activating enzyme, is present in rat testis from fetal to adult life (Bates et al. 1999) and that testis D2 activity is highly sensitive to hypothyroidism (Wagner et al. 2003). Nevertheless, the exact cellular localization of D2 expression in this organ remains unclear.

The present study was undertaken to further analyze the D2 expression in adult rat testis. We aimed to determine the testicular cell subtypes in which this enzyme is expressed using a combination of real-time PCR analysis, in situ hybridization, and D2 activity in somatic and germ cell fractions. D2 expression in other tissues of male reproductive system of rats was also evaluated.

\section{Material and Methods}

\section{Animals}

The experiments were performed on 100- to 120-day-old male Wistar rats, housed under conditions of controlled lighting and temperature, fed a commercial diet and water was available ad libitum. For real-time PCR and deiodinase assays, rats were made hypothyroid by administering $0.03 \%$ methimazole (MMI; Biolab, SP, Brazil) in the drinking water for 4 weeks to reduce their plasma $\mathrm{T}_{4}$ levels. Control rats received regular drinking water ad libitum. Euthanasia was performed in a $\mathrm{CO}_{2}$ chamber and tissues were rapidly removed, frozen in liquid nitrogen, and stored at $-70{ }^{\circ} \mathrm{C}$ for subsequent D2 activity determination. For isolation of cell fractions, testes were removed, decapsulated, and immediately used. All animals were carefully monitored and maintained in accordance with ethical recommendations of the Brazilian
Veterinary Medicine Council and the Brazilian College of Animal Experimentation.

\section{Real-time PCR analysis}

RNA was reverse transcribed with the SuperScript Preamplification System for First Strand cDNA Synthesis (Invitrogen Corp.) using $3 \mu \mathrm{g}$ total RNA and $100 \mathrm{ng}$ random hexamers. Reactions for the quantification of target mRNAs were performed in an ABI Prism 7500 Sequence Detection System (Applied Biosystems, Warrington, UK) using the SYBR Green PCR Master Mix (Applied Biosystems) and cyclophilin as a housekeeping internal control. Samples were run in duplicate. The cycle conditions were $94^{\circ} \mathrm{C} \times 5 \mathrm{~min}$ (Hot Start), 40 cycles of $94{ }^{\circ} \mathrm{C} \times 30 \mathrm{~s} ; 58{ }^{\circ} \mathrm{C} \times 30 \mathrm{~s} ; 72{ }^{\circ} \mathrm{C} \times$ $45 \mathrm{~s}$ and a final $1 \mathrm{~min}$ extension period. Initially, standard curves representing five-point serial dilution of mixed cDNAs of the control and experimental groups were analyzed and used as calibrators to determine the relative quantification of product generated in the exponential phase of the amplification curve. Comparable efficiency was observed presenting $r^{2}>0.99$. Sample quantification was calculated by the standard curve and corrected by the internal control cyclophilin in all experiments. Oligonucleotides for rat D2 and cyclophilin were $\left(5^{\prime}\right.$-TTCTCCAACTGCCTCTTCCTG-3 $3^{\prime}$ and $5^{\prime}$-CCCATCAGCGGTCTTCTCC- $3^{\prime}$ ) and $\left(5^{\prime}\right.$-GCCGATGACGAGCCCTTG- $3^{\prime}$ and $5^{\prime}$-TGCCGCCAGTGCCATTATG-3') respectively.

\section{In situ hybridization histochemistry}

Male euthyroid adult rats were anesthetized with sodium pentobarbital (50 mg/kg body weight i.p.), blood was taken from the inferior vena cava and the animals were immediately perfused transcardially with $20 \mathrm{ml} 0 \cdot 01 \mathrm{M}$ PBS (pH 7.4) containing $15000 \mathrm{IU} / 1$ heparin sulfate followed by $150 \mathrm{ml}$ of $4 \%$ paraformaldehyde in PBS. The testes were removed, postfixed by immersion in the same fixative for $2 \mathrm{~h}$ at room temperature and then cryoprotected in 20\% sucrose in PBS at $4{ }^{\circ} \mathrm{C}$ overnight. The testes were then placed in a cryomold, covered with optimal cutting temperature (OCT) compound (Tissue Tek, Nussloch, Germany) and snap frozen on dry ice. Serial $14 \mu \mathrm{m}$ thick coronal sections were cut on a cryostat (Leica CM3050 S, Leica Microsystems GmbH, Nussloch, Germany) and adhered to Superfrost/Plus glass slides (Fisher Scientific, Pittsburg, PA, USA). The tissue sections were desiccated overnight at $42{ }^{\circ} \mathrm{C}$ and stored at $-80{ }^{\circ} \mathrm{C}$ until prepared for in situ hybridization histochemistry.

Methods for double-labeling in situ hybridization have been described in detail elsewhere (Kakucska et al. 1992, Tu et al. 1997). Tissue sections were hybridized with an 800 bp single-strand $\left[{ }^{35} \mathrm{~S}\right]-\mathrm{UTP}-$ labeled cRNA probe complementary to the entire coding region of the rat Dio2 gene. Briefly, the hybridization was performed under plastic coverslips in a buffer containing $50 \%$ formamide, $2 \times$ standard 
sodium citrate $(2 \times \mathrm{SSC}), 10 \%$ dextran sulfate, $0 \cdot 5 \%$ sodium dodecyl sulfate, $250 \mu \mathrm{g} / \mathrm{ml}$ denatured salmon sperm DNA, and $6 \times 10^{5}$ c.p.m. of radiolabeled probe for $16 \mathrm{~h}$ at $56^{\circ} \mathrm{C}$. Slides were dipped into Kodak NTB2 autoradiography emulsion (Eastman Kodak) and the radiograms developed after 6 days of exposure at $4{ }^{\circ} \mathrm{C}$. After being cleared in graded solutions of ethanol and Histosol (National Diagnostics, Atlanta, GA, USA), the sections were stained or not with haematoxylin and eosin, coverslipped in Histomount (National Diagnostics), and the radiograms visualized and photographed under bright- or dark-field illumination with a Zeiss III (Carl Zeiss Inc., Thornwood, NY, USA) or Provis AX-70 Olympus (Olympus America Inc., Lake Sucess, NY, USA) microscope.

\section{High-resolution light microscopy (HRLM)}

Since frozen sections subjected to in situ hybridization analyses are very thick $(\sim 14 \mu \mathrm{m})$ and show low resolution, we used a high-resolution approach to identify fine details of germ and Sertoli cells under light microscopy (ChiariniGarcia \& Russell 2001). Staging of the spermatogenic cycle was previously determined, based on the youngest generation of spermatids and development of their acrosomal system. Fifteen minutes after i.p. heparin injection (125 IU $/ \mathrm{kg}$ body weight), rat testes were briefly washed with saline by perfusion via the cardiac route and subsequently perfusedfixed with glutaraldehyde in $0 \cdot 05 \mathrm{M}$ cacodylate buffer $(\mathrm{pH}$ $7 \cdot 4)$. After that, testes were removed and sliced in small slabs that were rinsed overnight in $0.05 \mathrm{M}$ cacodylate buffer and post-fixed in 1\% osmium: $1.25 \%$ potassium ferrocyanide mixture, dehydrated in a graded series of ethanol, infiltrated, and embedded in Araldite. From the araldite-embedded blocks, $1 \mu \mathrm{m}$ thick sections were obtained with a Reichert Jung microtome (model 1140/autocut, Tissue Tek) and stained with toluidine blue-borate for further analysis at a BX-41 Olympus microscope (Olympus). Photomicrographs were taken with a Q-color 3 digital camera (Olympus).

\section{Isolation of cell fractions}

Testicular cell fractions of euthyroid and hypothyroid rats were prepared as previously described (Gelain et al. 2003). Briefly, testes were removed, decapsulated, and enzymatically digested with $30 \mathrm{ml}$ trypsin (Sigma-Aldrich) and $250 \mu \mathrm{l}$ DNase (Sigma-Aldrich) for $15 \mathrm{~min}$ at $37^{\circ} \mathrm{C}$. This homogenate was centrifuged for $5 \mathrm{~min}$ at $400 \mathrm{~g}$ and the pellet was washed with $1 \%$ soybean trypsin inhibitor (Sigma-Aldrich) in complete Hanks balanced salt solution (HBSS). Cells were then centrifuged for $5 \mathrm{~min}$ at $400 \mathrm{~g}$ and the pellet was collected and incubated with $20 \mathrm{ml}$ collagenase (SigmaAldrich) for $20 \mathrm{~min}$ at $37^{\circ} \mathrm{C}$. This homogenate was centrifuged for $5 \mathrm{~min}$ at $400 \mathrm{~g}$ and the pellet was resuspended with HBSS and filtered in a $100 \mu \mathrm{m}$ diameter nylon mesh
(Sigma-Aldrich) in order to separate germ from somatic cells. Cell fractions were immediately used for the enzymatic assay as described below.

\section{Deiodinase assay}

D2 assay was performed as previously described (Wagner et al. 2003) for both euthyroid and hypothyroid groups. Tissue samples were homogenized and sonicated on ice in buffer containing $1 \times \mathrm{PE}(0 \cdot 1 \mathrm{M}$ potassium phosphate and $1 \mathrm{mM}$ EDTA), $0 \cdot 25 \mathrm{M}$ sucrose, and $10 \mathrm{mM}$ dithiothreitol (DTT; Invitrogen), $\mathrm{pH} 6 \cdot 9$. The reaction mixtures containing 100 $250 \mu \mathrm{g}$ tissue proteins were incubated in a total volume of $300 \mu 1$ with 100000 c.p.m. of $\mathrm{L}-\left[{ }^{125} \mathrm{I}^{\mathrm{T}} \mathrm{T}_{4}\right.$ (Amersham) purified by LH-20 sephadex column (Pharmacia); $1 \mathrm{nM}$ unlabeled $\mathrm{T}_{4}, 20 \mathrm{mM}$ DTT, and $1 \mathrm{mM}$ propylthiouracyl (PTU; Sigma-Aldrich) in PE buffer at $37^{\circ} \mathrm{C}$ for $2-3 \mathrm{~h}$. Reactions were determined by the addition of $200 \mu$ horse serum and $100 \mu \mathrm{l} 50 \%$ trichloroacetic acid. After centrifugation at $12000 \mathrm{~g}$ for $3 \mathrm{~min}$, free ${ }^{125} \mathrm{I}$ in the supernatant was counted with a gamma counter. The $K_{\mathrm{m}} / V_{\max }$ determinations were performed with $0 \cdot 25,0 \cdot 5,1,3$, and $10 \mathrm{nM}$ unlabeled $\mathrm{T}_{4}$. Activity is expressed as femtomoles iodide generated/min per mg protein. All reactions were performed in duplicates or triplicates and the experiments were repeated twice.

\section{Statistical analysis}

Data were analyzed using PRISM software (GraphPad Software Inc., San Diego, CA, USA) and results were shown as means \pm s.D. Four to six animals were used per group per experiment. Comparisons between two groups were performed using student's $t$-test. $P<0 \cdot 05$ was considered statistically significant.

\section{Results}

\section{Real-time PCR analysis}

D2 transcript levels were evaluated in germ and somatic cells isolated from euthyroid and hypothyroid rat testis by real-time PCR. Although D2 mRNA was detected in both germ and somatic cells, D2 mRNA levels were significantly higher in germ than in somatic cells $(6 \cdot 94 \pm 1 \cdot 49$ vs $2 \cdot 32 \pm 0 \cdot 79$ arbitrary units (au) respectively; $P=0 \cdot 017$ ). Hypothyroidism induced a significantly increase in D2 expression in germ cells $(6 \cdot 94 \pm 1.49$ vs $8 \cdot 78 \pm 5.43 \mathrm{au}, P=0.002)$ but did not change D2 mRNA levels in somatic cells significantly $(2 \cdot 12 \pm 0 \cdot 79$ vs $2 \cdot 88 \pm 1 \cdot 39$ au, $P=0 \cdot 5)$.

\section{Cellular localization of D2 transcripts in rat testis}

To address the specific localization of D2 within germ cells of the seminiferous epithelium, we performed in situ 

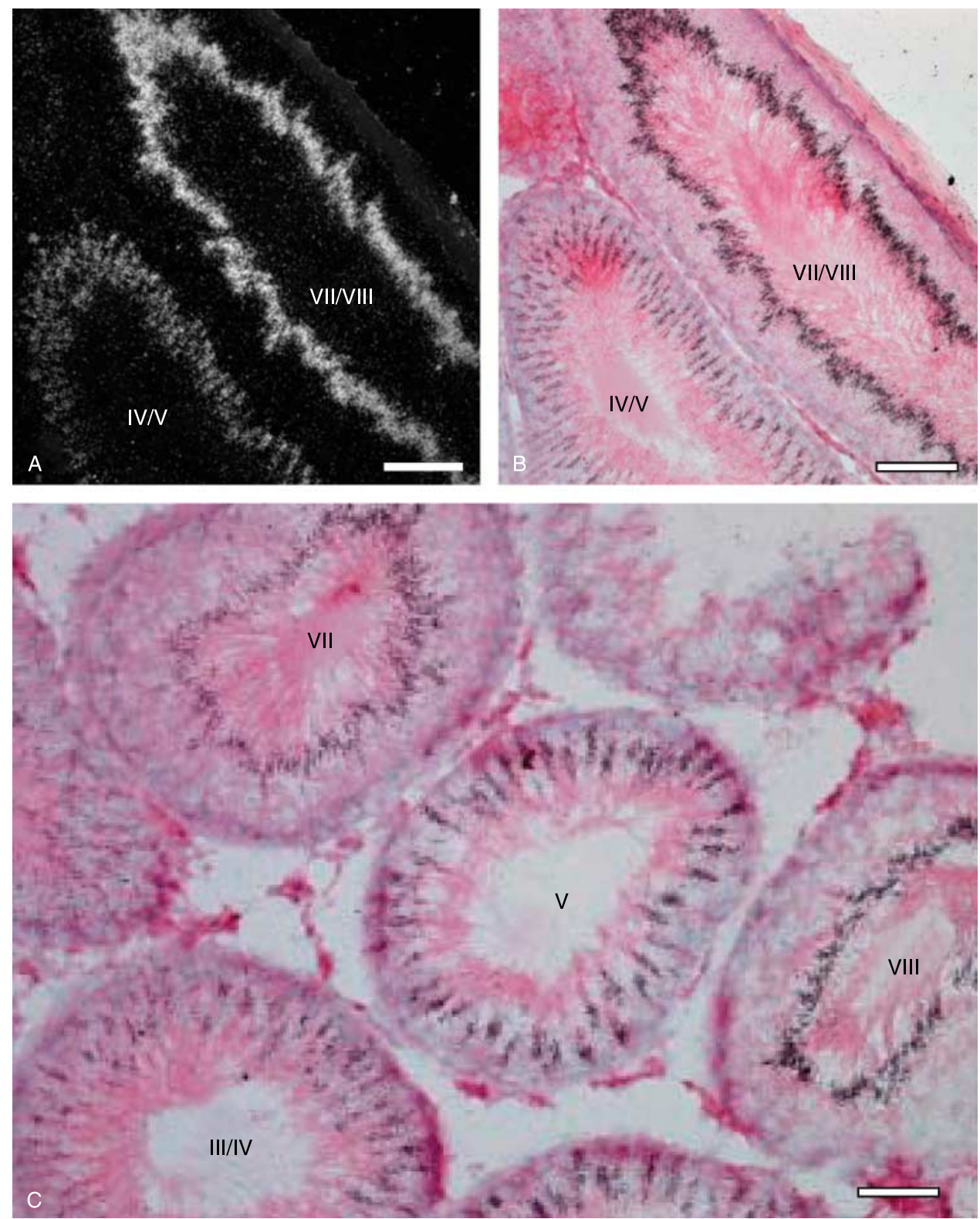

Figure 1 In situ hybridization histochemistry autoradiograms of type 2 iodothyronine deiodinase (D2) in rat seminiferous epithelium. Dark- (A) and bright- (B) field microscopy shows identical fields of part of the seminiferous epithelium (longitudinal sections) with intense labeling for D2 mRNA in spermatids at stages III/IV and VII/VIII of the cycle. In (C), cross-sectioned seminiferous tubules at different stages of the cycle (III/IV, V, VII, and VIII) show D2 labeling coinciding with the localization of spermatids. Note that these cells are in differentiation process and occupy different heights of the seminiferous epithelium. Bars represent $\sim 50 \mu \mathrm{m}$.

hybridization histochemistry in testes from euthyroid adult rats. Evaluation of the seminiferous epithelium at dark- and bright-field microscopy showed that spermatids were intensely labeled for D2 mRNA (Fig. 1A). This cell type could be observed at different heights in the seminiferous epithelium because of the differentiation process when round spermatids become spermatozoa (spermiogenic phase; Chiarini-Garcia \& Russell 2001). Remarkably, we observed that elongated spermatids were consistently and preferentially labeled for D2. For instance, at stage III/IV of the spermatogenic cycle, when elongated spermatids are localized more internally in the seminiferous epithelium, 
labeling for D2 mRNA was observed at the same cell position (Fig. 1B and C). At several other stages of the cycle, a dense D2 labeling coincided with the localization of more mature elongated spermatids (Fig. 1C). Control hybridization (D2 sense probe) was negative (data not shown).

For precise identification of cycle staging, we next compared in situ hybridization sections with high-resolution sections from rat testes. D2 labeling corresponded to the position of elongated spermatids in different stages of the spermatogenic cycle (Fig. 2). At stage V, elongated spermatids are localized mainly in the middle part of the tubule, corresponding with the D2-positive cells (Fig. 2A and B). A dense D2 labeling coincided with the localization of more mature elongated spermatids close to the tubule lumen (Stage VII/VIII; Fig. 2C and D).

In contrast to the dense deiodinase labeling on spermatids, other spermatogenic cells, such as spermatogonia and spermatocytes, were virtually negative. Of note, interstitial cells (Fig. 1C) were negative for the presence of D2 mRNA.
D2 activity in separated testicular cell fractions and other tissues

To provide additional evidence for D2 localization in germ cells, we next evaluated the enzyme activity in two separated testicular somatic and germinative enriched cell fractions of both euthyroid and hypothyroid groups. D2 activity was mainly detected in the germ cell fraction from testes of euthyroid rats $(0.23 \pm 0.003$ vs $0.02 \pm 0.013 \mathrm{fmol} / \mathrm{min}$ per $\mathrm{mg}$ protein), further confirming the $\mathrm{D} 2$ expression profile obtained by real-time PCR and in situ hybridization. The $5^{\prime}$ deiodination activity in isolated germ cells was then characterized by kinetic studies that showed a typical $K_{\mathrm{m}}$ $\left(\mathrm{T}_{4}\right)$ for D2 $(1.1 \mathrm{nM})$ and $V_{\max }$ of $0.63 \mathrm{fmol} \mathrm{T}_{4} / \mathrm{min}$ per $\mathrm{mg}$ protein (Fig. 3A). D2 activity was completely abolished by iopanoic acid $(100 \mu \mathrm{M})$ and higher $\mathrm{T}_{4}$ concentration $(100 \mathrm{nM})$. Hypothyroidism induced a significant increase in enzyme activity (approximately twofold).

D2 expression was also evaluated in other tissues of the adult reproductive system. D2 activity was readily detected in
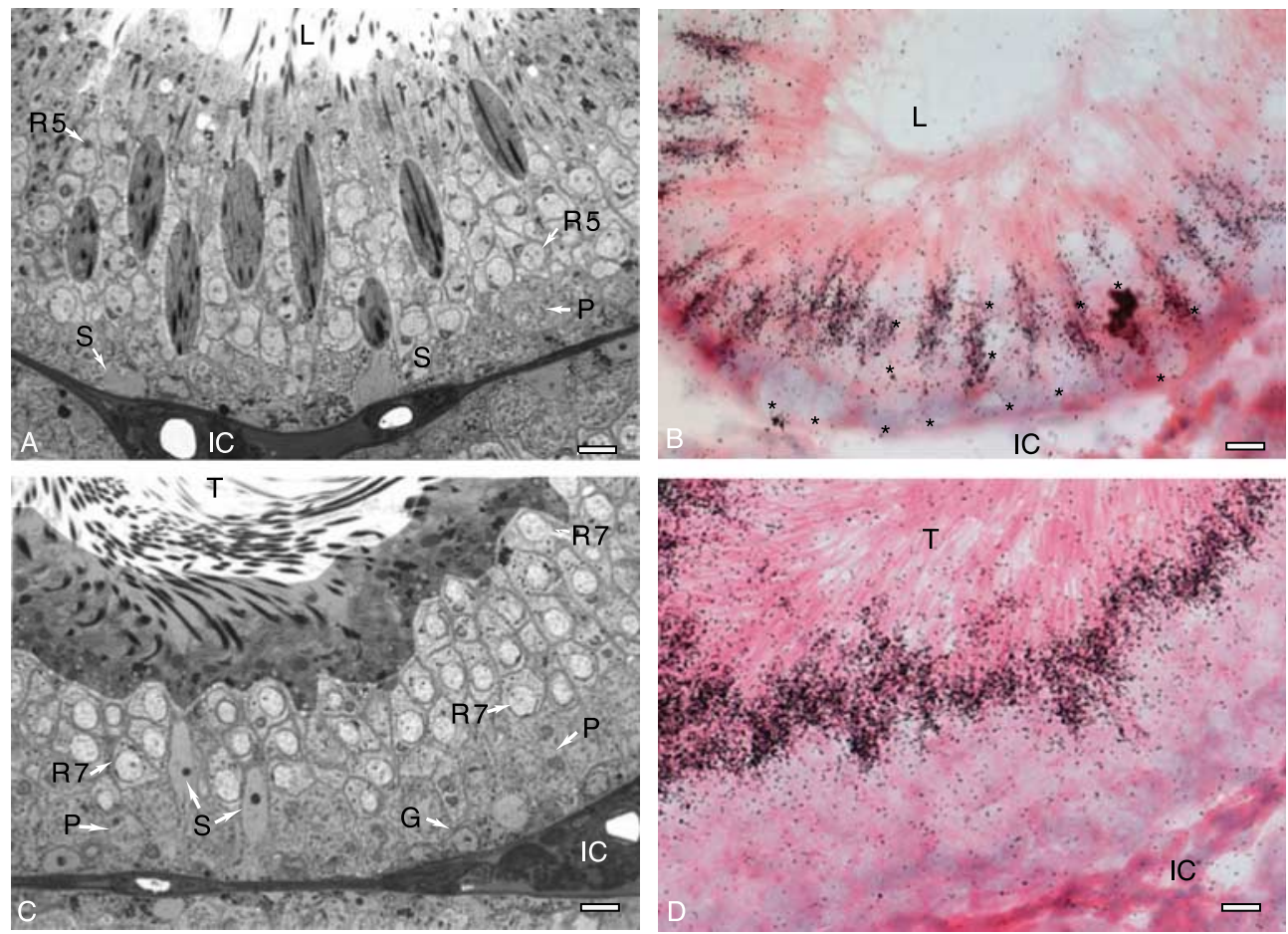

Figure 2 Comparison of the positions of spermatids and D2 labeling within the seminiferous epithelium of rats by high-resolution light microscopy (HRLM; A and C) and in situ hybridization (B and D). A and B shows the same stage $(\mathrm{V})$ of the cycle. Observe that the position of elongate spermatids $(A$, dark transparent areas) coincide with the position of D2 labeling in B. Other cells of the seminiferous epithelium, such as spermatogonia $(\mathrm{G})$, pachytene $(\mathrm{P})$, round spermatids $(\mathrm{R})$, and Sertoli cells $(\mathrm{S})$, distinguished in $\mathrm{A}$, are apparently not labeled in B (asterisks). L, lumen. In C and D, at stage VII, the elongated spermatids are almost ready to be released and, in this way, they are concentrated and positioned as a palisade on the surface of the epithelium (C, dark transparent area). In D, the dense D2 labeling is localized to the same position where the elongated spermatids are seen and virtually absent in the rest of the seminiferous epithelium. T, high concentration of spermatid tails. Note that the difference between the number of spermatids in HRLM and the high concentration of D2 labeling by in situ hybridization is due to the difference of section thickness ( 1 and $14 \mu \mathrm{m}$ respectively). R5, step 5 round spermatid; R7, step 7 round spermatid; IC, interstitial cells. Bars represent $\sim 12 \mu \mathrm{m}$. 


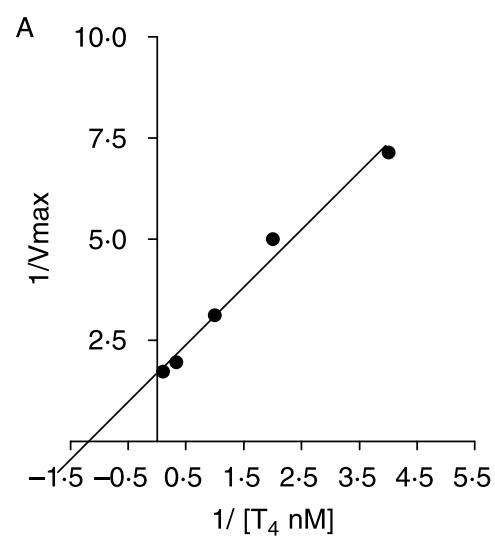

B

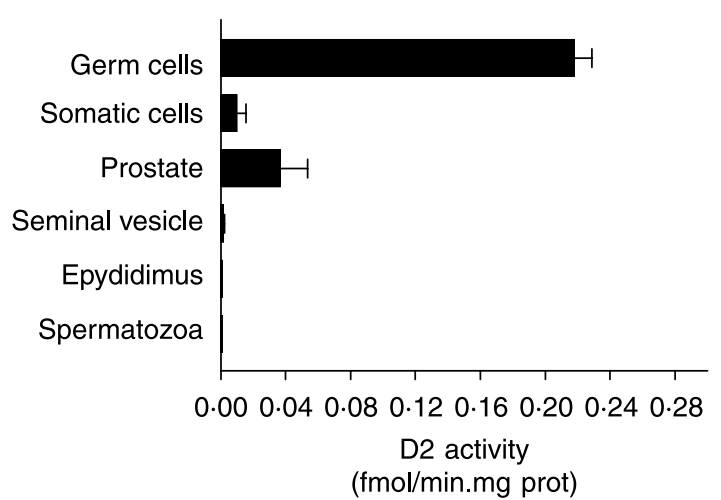

Figure 3 (A). D2 kinetics from testicular germ cell samples in adult rat. Representative Lineweaver-Burk plot of $\mathrm{T}_{4}$ deiodination catalyzed by D2. Kinetic constants were calculated to be $K_{\mathrm{m}} 1 \cdot 1 \mathrm{nM}$ and $V_{\max }$ $0.63 \mathrm{fmol} / \mathrm{min}$ per $\mathrm{mg}$ protein. (B). D2 activity in rat reproductive organs. Data are representative of three experiments.

prostate in euthyroid rats and increased several fold in hypothyroid animals $(0.03$ vs $0.093 \pm 0.014 \mathrm{fmol} / \mathrm{min}$ per mg protein respectively, $P<0 \cdot 001)$. D2 activity was undetectable in epididymus, PBS-washed seminal vesicle, and spermatozoa (Fig. 3B).

\section{Discussion}

This study demonstrates for the first time that D2 expression is highly concentrated in a specific type of germ cells in the seminiferous epithelium of adult rat testis. By in situ hybridization histochemistry, using a probe complementary to the coding sequence of rD2mRNA, we have shown that Dio2 transcripts are localized almost exclusively in spermatids undergoing maturation. D2 mRNA and activity measured in isolated somatic and germinative cell fractions confirmed the hybridization results. In the other tissues of male reproductive tract evaluated, D2 expression was only detected in the prostate. Altogether, our results provide direct evidence for a specific localization and activity of D2 in elongated spermatids within the testis.

Thyroid hormones play an important role in rat testicular development, especially on differentiation of Sertoli cells and spermatogenesis in the pre-pubertal stage (Holsberger \& Cooke 2005). Experimentally induced neonatal hypothyroidism has been shown to lengthen the proliferative period of Sertoli cells, resulting in a significant increase in adult testis size and sperm production (Hess et al. 1993). In contrast, experimental hyperthyroidism induces Sertoli cell differentiation (Jannini et al. 1993). Furthermore, as recently reported in the $r d w$ rats with congenital hypothyroidism, thyroid hormone seems to be important for the maintenance of testicular structure after full maturation (Sakai et al. 2004). Although thyroid hormones are the best described modulators of the developing testis, their role in the adult organ is still undefined (Holsberger \& Cooke 2005). A critical development in this field was the finding that TRs are also present, at a low but significant level, in rat and human adult testis (Buzzard et al. 2000, Jannini et al. 2000), indicating that $\mathrm{T}_{3}$ may have a direct effect on the adult organ.

We and others have previously shown that D2 is expressed in adult mice and rat testis, and that its activity is significantly induced by hypothyroidism (Bates et al. 1999, Wagner et al. 2003). Here, we further demonstrate that D2 expression is cell type-specific by real-time PCR analysis, in situ hybridization histochemistry, and enzymatic assays. Elongated spermatids at different stages of maturation appear to be the predominant germ cell positive for D2, whereas other germ cells, i.e. spermatogonia, spermatocytes, and round spermatids, are negative for D2.

In mammals, spermatogenesis is a complex process in which stem cells, the spermatogonia, go through a differentiation step followed by subsequent divisions and differentiation into mature spermatozoa (Russell et al. 1990). The spermiogenic phase is one of the most extraordinary cell transformations in the body. Despite numerous studies aimed at elucidating the hormonal control of spermatogenesis, there is still a debate as to which hormones are involved and at which sites they promote cell maturation and progression to the next stage of spermatogenic cycle (El Shennawy et al. 1998, Holdcraft \& Braun 2004). High D2 activity is typically found in specialized tissues, such as the anterior pituitary, $\mathrm{CN}$, and BAT, where $\mathrm{T}_{3}$ concentration seems to be critical (Bianco et al. 2002). The finding that D2 is highly expressed in the elongating spermatid, at the middle of the spermiogenic process, suggests a role for $T_{3}$ in spermatid differentiation. It is important to note that TR $\alpha 1$, one of the functional TR isoforms, and thyroid hormone transporters known to facilitate cellular thyroid 
hormone uptake have been identified in germ cells, not only in adult rats but also in humans (Buzzard et al. 2000, Jannini et al. 2000, Suzuki et al. 2003). Since the biological effects induced by thyroid hormones are mediated by specific nuclear receptors, it is possible that the intracellular D2-generated $\mathrm{T}_{3}$ may induce spermatids differentiation playing a role in their maturation process.

Previous studies have shown that hypothyroidism in postpubertal period has little effect on testis, and fertility is seldom compromised (Maia et al. 1990, Jannini et al. 1995, Schneider et al. 2006). A potential explanation for these observations is that increased D2 activity, induced by the hypothyroidism, maintains $T_{3}$ concentration at normal levels, thus preserving the spermiogenic process and fertility from this adverse effect. Interestingly, $5^{\prime}$ deiodination activity was also reported in seminal plasma of pre-pubertal pigs (Brzezinska-Slebodzinska et al. 2000).

Based on the findings of this study, it is somewhat intriguing that mice lacking the Dio2 (Dio2-/-) gene appear to have normal reproductive function (St Germain et al. 2005). The most likely explanation is that the normal circulating thyroid hormone levels observed in these animals are adequate to allow tissue development and function (de Jesus et al. 2001).

In conclusion, we have shown that D2 expression is highly concentrated in elongated spermatids, whereas other germ cells and Sertoli cells of the seminiferous epithelium are virtually negative for this enzyme. These results suggest that thyroid hormone might have an effect on spermatogenesis in the adult rat testis, specifically on the spermiogenic or differentiation phase.

\section{Acknowledgements}

Coordenação de Aperfeiçoamento de Pessoal de Nível Superior (CAPES), Conselho Nacional de Desenvolvimento Científico e Tecnológico (CNPq), Fundação de Amparo à Pesquisa do Estado do Rio Grande do Sul (FAPERGS), and Fundo de Incentivo a Pesquisa (FIPE), Brazil. The authors declare that there is no conflict of interest that would prejudice the impartiality of this scientific work.

\section{References}

Bates JM, St Germain DL \& Galton VA 1999 Expression profiles of the three iodothyronine deiodinases, D1, D2, and D3, in the developing rat. Endocrinology 140 844-851.

Berry MJ, Maia AL, Kieffer JD, Harney JW \& Larsen PR 1992 Substitution of cysteine for selenocysteine in type I iodothyronine deiodinase reduces the catalytic efficiency of the protein but enhances its translation. Endocrinology 131 1848-1852.

Bianco AC, Salvatore D, Gereben B, Berry MJ \& Larsen PR 2002

Biochemistry, cellular and molecular biology, and physiological roles of the iodothyronine selenodeiodinases. Endocrine Reviews 23 38-89.
Brzezinska-Slebodzinska E, Slebodzinski AB \& Kowalska K 2000 Evidence for the presence of $5^{\prime}$-deiodinase in mammalian seminal plasma and for the increase in enzyme activity in the prepubertal testis. International Journal of Andrology 23 218-224.

Buzzard JJ, Morrison JR, O'Bryan MK, Song Q \& Wreford NG 2000 Developmental expression of thyroid hormone receptors in the rat testis. Biology of Reproduction 62 664-669.

Canale D, Agostini M, Giorgilli G, Caglieresi C, Scartabelli G, Nardini V, Jannini EA, Martino E, Pinchera A \& Macchia E 2001 Thyroid hormone receptors in neonatal, prepubertal, and adult rat testis. Journal of Andrology 22 284-288.

Carani C, Isidori AM, Granata A, Carosa E, Maggi M, Lenzi A \& Jannini EA 2005 Multicenter study on the prevalence of sexual symptoms in male hypo- and hyperthyroid patients. Journal of Clinical Endocrinology and Metabolism $906472-6479$.

Chiarini-Garcia H \& Russell LD 2001 High-resolution light microscopic characterization of mouse spermatogonia. Biology of Reproduction 65 1170-1178.

Croteau W, Whittemore SL, Schneider MJ \& St Germain DL 1995 Cloning and expression of a cDNA for a mammalian type III iodothyronine deiodinase. Journal of Biological Chemistry 270 16569-16575.

Gelain DP, de Souza LF \& Bernard EA 2003 Extracellular purines from cells of seminiferous tubules. Molecular and Cellular Biochemistry 245 1-9.

St Germain DL, Hernandez A, Schneider MJ \& Galton VA 2005 Insights into the role of deiodinases from studies of genetically modified animals. Thyroid 15 905-916.

Hess RA, Cooke PS, Bunick D \& Kirby JD 1993 Adult testicular enlargement induced by neonatal hypothyroidism is accompanied by increased Sertoli and germ cell numbers. Endocrinology 132 2607-2613.

Holdcraft RW \& Braun RE 2004 Hormonal regulation of spermatogenesis. International Journal of Andrology 27 335-342.

Holsberger DR \& Cooke PS 2005 Understanding the role of thyroid hormone in Sertoli cell development: a mechanistic hypothesis. Cell and Tissue Research 322 133-140.

Jannini EA, Ulisse S, Piersanti D, Carosa E, Muzi P, Lazar J \& D’Armiento M 1993 Early thyroid hormone treatment in rats increases testis size and germ cell number. Endocrinology 132 2726-2728.

Jannini EA, Ulisse S \& D'Armiento M 1995 Thyroid hormone and male gonadal function. Endocrine Reviews 16 443-459.

Jannini EA, Crescenzi A, Rucci N, Screponi E, Carosa E, de Matteis A, Macchia E, d'Amati G \& D'Armiento M 2000 Ontogenetic pattern of thyroid hormone receptor expression in the human testis. Journal of Clinical Endocrinology and Metabolism 85 3453-3457.

de Jesus LA, Carvalho SD, Ribeiro MO, Schneider M, Kim SW, Harney JW, Larsen PR \& Bianco AC 2001 The type 2 iodothyronine deiodinase is essential for adaptive thermogenesis in brown adipose tissue. Journal of Clinical Investigation 108 1379-1385.

Kakucska I, Rand W \& Lechan RM 1992 Thyrotropin-releasing hormone gene expression in the hypothalamic paraventricular nucleus is dependent upon feedback regulation by both triiodothyronine and thyroxine. Endocrinology 130 2845-2850.

Maia AL, Favaretto AL, Antunes-Rodrigues J, Iazigi N \& Lamano-Carvalho TL 1990 Spermatogenic and steroidogenic testicular function in hypothyroid pubertal rats. Brazilian Journal of Medical and Biological Research 23 625-628.

Maia AL, Kim BW, Huang SA, Harney JW \& Larsen PR 2005 Type 2 iodothyronine deiodinase is the major source of plasma $T_{3}$ in euthyroid humans. Journal of Clinical Investigation 115 2524-2533.

Oppenheimer JH, Schwartz HL \& Surks MI 1974 Tissue differences in the concentration of triiodothyronine nuclear binding sites in the rat: liver, kidney, pituitary, heart, brain, spleen, and testis. Endocrinology 95 897-903.

Russell LD, Ettlin RA, Sinha Hikim AP \& Clegg ED 1990 Histological and Histopathological Evaluation of the Testis.. 1, Clearwater, FL: Cache River Press.

Sakai Y, Yamashina S \& Furudate S 2004 Developmental delay and unstable state of the testes in the $r d w$ rat with congenital hypothyroidism. Development, Growth and Differentiation 46 327-334. 
Salvatore D, Low SC, Berry M, Maia AL, Harney JW, Croteau W, St Germain DL \& Larsen PR 1995 Type 3 lodothyronine deiodinase: cloning, in vitro expression, and functional analysis of the placental selenoenzyme. Journal of Clinical Investigation 96 2421-2430.

Schneider MJ, Fiering SN, Thai B, Wu SY, St Germain E, Parlow AF, St Germain DL \& Galton VA 2006 Targeted disruption of the type 1 selenodeiodinase gene (Dio1) results in marked changes in thyroid hormone economy in mice. Endocrinology 147 580-589.

El Shennawy A, Gates RJ \& Russell LD 1998 Hormonal regulation of spermatogenesis in the hypophysectomized rat: cell viability after hormonal replacement in adults after intermediate periods of hypophysectomy. Journal of Andrology 19 320-334 (Discussion 341-322).

Streckfuss F, Hamann I, Schomburg L, Michaelis M, Sapin R, Klein MO, Kohrle J \& Schweizer U 2005 Hepatic deiodinase activity is dispensable for the maintenance of normal circulating thyroid hormone levels in mice. Biochemical and Biophysical Research Communications 337 739-745.
Suzuki T, Onogawa T, Asano N, Mizutamari H, Mikkaichi T, Tanemoto M, Abe M, Satoh F, Unno M, Nunoki K et al. 2003 Identification and characterization of novel rat and human gonad-specific organic anion transporters. Molecular Endocrinology 17 1203-1215.

Tu HM, Kim SW, Salvatore D, Bartha T, Legradi G, Larsen PR \& Lechan RM 1997 Regional distribution of type 2 thyroxine deiodinase messenger ribonucleic acid in rat hypothalamus and pituitary and its regulation by thyroid hormone. Endocrinology 138 3359-3368.

Wagner MS, Morimoto R, Dora JM, Benneman A, Pavan R \& Maia AL 2003 Hypothyroidism induces type 2 iodothyronine deiodinase expression in mouse heart and testis. Journal of Molecular Endocrinology 31 541-550.

Received 5 March 2007

Accepted 10 April 2007

Made available online as an Accepted Preprint 11 April 2007 